\title{
Growth and Fruiting of Young 'Concord' Grapevines in Relation to Reserve Nitrogen and Carbohydrates
}

\author{
Lailiang Cheng ${ }^{1}$ and Guohai Xia ${ }^{2}$ \\ Department of Horticulture, Cornell University, Ithaca, NY 14853 \\ Terry Bates \\ Department of Horticultural Sciences, New York State Agricultural Experiment Station, Geneva, NY 14456
}

\begin{abstract}
AdDitional INDEX words. $\mathrm{CO}_{2}$ assimilation, foliar nitrogen, nitrogen fertigation, nitrogen remobilization, total nonstructural carbohydrates, Vitis labruscana

Aвstract. One-year-old 'Concord'grapevines (Vitis labruscana Bailey) were fertigated with 0,5, 10, 15, or 20 mm nitrogen by using a modified Hoagland's solution for 8 weeks during active vine growth in summer. Half of the vines at each $\mathbf{N}$ concentration were sprayed with $3 \%$ foliar urea twice in late September while the rest served as controls. After natural leaf fall, all the vines were overwintered in a cold room $\left(2\right.$ to $\left.4^{\circ} \mathrm{C}\right)$. Four vines from each treatment were destructively sampled before budbreak for reserve $\mathrm{N}$ and carbohydrate analysis. The remaining vines were supplied with either no $\mathrm{N}$ or sufficient $\mathrm{N}(10 \mathrm{~mm} \mathrm{~N})$ from 2 weeks before bloom to 1 month after bloom. All the vines were destructively harvested at 1 month after bloom. Total amount of $\mathbf{N}$ in dormant vines increased with increasing $\mathbf{N}$ fertigation concentration. Total nonstructural carbohydrates (TNC) increased with increasing $\mathrm{N}$ fertigation concentration from 0 to $10 \mathrm{~mm}$, and then leveled off with further rises in $\mathrm{N}$ supply. Foliar urea application increased total $\mathrm{N}$ but decreased TNC of dormant vines at each given $\mathrm{N}$ fertigation level. When no $\mathrm{N}$ was provided during the regrowth period, vine total leaf area, fruit yield, and total dry weight increased with increasing N supply from fertigation the previous year. Vines sprayed with foliar urea the previous fall produced a larger total leaf area, a higher yield, and a higher total vine dry weight at each given $\mathbf{N}$ fertigation concentration. Providing vines with sufficient $\mathbf{N}$ during the regrowth period significantly increased total leaf area, fruit yield, and vine total dry weight across the previous $\mathbf{N}$ fertigation concentrations, but vines sprayed with foliar urea still had a larger leaf area, a higher yield, and a higher total vine dry weight at each given $\mathbf{N}$ fertigation concentration. Therefore, we conclude that both vegetative growth and fruiting of young 'Concord' vines are largely determined by reserve nitrogen, not by reserve carbohydrates, and that current-season $\mathrm{N}$ supply plays a very important role in sustaining vine growth and development, especially fruit growth.
\end{abstract}

Both reserve nitrogen and carbohydrates are essential for the initial growth and development of grapevines in spring, as they provide energy and building blocks for the new growth before any net carbon assimilation and significant root uptake of $\mathrm{N}$ takes place (Wermelinger, 1991; Williams, 1991; Yang and Hori, 1980). Any environmental factors or cultural practices that alter the demand-supply relationships of $\mathrm{N}$ and carbohydrates (cropload, water and nutrient stresses, and diseases and pests, etc.) will likely affect both reserve $\mathrm{N}$ and carbohydrate status of the vine, and consequently influence vine performance the following season. Compared with other grape-growing regions of the world, there is a very short leaf-retention period after harvesting the crop (anywhere between a few days to 3 to 4 weeks) in the Great Lakes region of North America (Howell, 2001). Considering that photosynthesis is limited during the postharvest period, grapevines may not be able to accumulate enough reserve carbohydrates, which may limit their growth and fruiting the following spring.

The notion that vine growth and fruiting in cool climate re-

Received for publication 2 Mar. 2004. Accepted for publication 4 May 2004. This work was supported in part by USDA Viticulture Consortium Program and New York Wine/Grape Foundation. The authors thank Drs. Anil Ranwala and Bill Miller for help with carbohydrate analysis, Mr. Richard Raba for assistance with plant materials, and Drs. Marvin Pritts and Stanly Howell for critical reading of the manuscript.

'To whom reprint requests should be addressed: fax: 607-255-4355; e-mail: LC89@Cornell.edu

${ }^{2}$ Permanent address: Department of Horticulture, Henan Agricultural University, Zhengzhou 450001, P.R. China. gions is limited by reserve carbohydrates has been long-standing. However, the evidence for this hypothesis is largely correlative. Complete defoliation at veraison or right after harvest significantly decreased vine growth and yield the following season (Howell et al., 1978; Scholefield et al., 1978). It is true that defoliation prior to natural leaf abscission reduced reserve carbohydrates in the dormant vine (Goffinet, 2001; Xia and Cheng, unpublished data), but it also decreased total $\mathrm{N}$ in dormant 'Concord' grapevines (Xia and Cheng, unpublished data) and apple (Malus $\times$ domestica Borkh.) trees (Faby and Naumann, 1986; Guak et al., 2001) by stopping $\mathrm{N}$ mobilization from leaves back to storage tissues and by decreasing root $\mathrm{N}$ uptake. In cool climate regions, rapid drop of temperature or killing frost after harvest may significantly reduce or even stop mobilization of $\mathrm{N}$ from leaves back to storage tissues during leaf senescence, and the short postharvest period may limit root $\mathrm{N}$ uptake from the soil as well. Therefore, it is unclear whether reserve $\mathrm{N}$ or reserve carbohydrates limit vine growth and fruiting in the spring.

Understanding the limitation of reserve $\mathrm{N}$ and reserve carbohydrates on growth and fruiting of grapevines is important for optimizing viticultural practices to improve growth and yield in cool climate regions. If vine growth and fruiting are mainly limited by carbohydrate reserves, cultural practices should be optimized to increase carbohydrate reserves. In contrast, if growth and fruiting are mainly determined by $\mathrm{N}$ reserves, $\mathrm{N}$ management practices that increase $\mathrm{N}$ storage would improve vine productivity. For young apple trees, it has been demonstrated that the initial growth in spring is primarily determined by reserve $\mathrm{N}$, not by 
reserve carbohydrates (Cheng and Fuchigami, 2002). However, it remains to be seen whether this holds true for reproductive growth. In this study, we used $\mathrm{N}$ fertigation during active vine growth in summer and foliar urea application in the fall to alter reserve $\mathrm{N}$ and carbohydrate status, and then determined both vegetative growth and fruiting the following season.

\section{Materials and Methods}

Plant culture, nitrogen treatments, and sampling. Oneyear-old, own-rooted 'Concord' grapevines were grown in sand culture in 18-L containers. Each vine was pruned to two nodes before budbreak. Plants were grown outdoors at Cornell Orchards in Ithaca, N.Y. (lat. $42^{\circ} 26^{\prime} \mathrm{N}$, long. $76^{\circ} 29^{\prime} \mathrm{W}$ ). At budbreak, extra shoots were removed and only two vegetative shoots were allowed to grow on each vine. Beginning from the second week after budbreak, each plant was supplied once a week with 500 $\mathrm{mL}$ of $10 \mathrm{~mm} \mathrm{~N}$, using Peters $20 \mathrm{~N}-4.4 \mathrm{P}-16.6 \mathrm{~K}$ water-soluble fertilizer with micronutrients (Scotts-Sierra Horticultural Products, Marysville, Ohio). Starting from 22 June 2001, when new shoots were approximately $35 \mathrm{~cm}$ long, uniform plants were selected and randomly assigned to one of the following five $\mathrm{N}$ treatments. Each plant was supplied twice weekly with $500 \mathrm{~mL}$ of a modified Hoagland's solution at an $\mathrm{N}$ concentration of 0,5 , 10,15 , or $20 \mathrm{~mm}$ (from $\mathrm{NH}_{4} \mathrm{NO}_{3}$ ) (Cheng and Fuchigami, 2000) for 8 weeks until $17 \mathrm{Aug}$. No additional $\mathrm{N}$ or other nutrients was provided to the roots for the rest of the growing season. There were four replications at each $\mathrm{N}$ fertigation treatment with six vines each in a completely randomized design. All plants had stopped their terminal growth by 15 Sept. Half of the vines (12) at each $\mathrm{N}$ fertigation treatment were sprayed with $3 \%$ urea twice (20 and 29 Sept.) while the rest served as unsprayed controls. Foliar urea application advanced leaf abscission by about $3 \mathrm{~d}$. By 25 Oct., leaf abscission was completed across all the treatments and all the vines were moved to a cold room $\left(2\right.$ to $\left.4{ }^{\circ} \mathrm{C}\right)$ with pots for overwintering.

Each vine was pruned to 20 nodes on 26 Mar. 2002 when they were still dormant. Right after pruning, four vines from each of the 10 treatment combinations were destructively sampled. Each vine was divided into 1-year-old cane, shank, and roots. All the samples were frozen at $-80^{\circ} \mathrm{C}$, freeze-dried, then ground to pass 1-mm screen. A composite sample was made for each vine based on its dry matter distribution among different parts after pruning to determine $\mathrm{N}$ and nonstructural carbohydrates.

The other eight vines from each treatment were transplanted into 18-L pots containing sand after their roots being thoroughly washed with tap water on 25 Apr. 2002. All the vines were grown outside under natural conditions. They were randomly divided into two groups: A and B. Starting from 2 weeks after budbreak, vines in group A received $2 \mathrm{~L}$ of $10 \mathrm{~mm} \mathrm{~N}$ from ${ }^{15} \mathrm{~N}$-depleted $\mathrm{NH}_{4} \mathrm{NO}_{3}$ $\left(0.03 \%{ }^{15} \mathrm{~N}\right.$ abundance; ) in a Hoagland's solution twice weekly until $30 \mathrm{~d}$ after bloom. Vines in group $\mathrm{B}$ received no $\mathrm{N}$ but all the other mineral nutrients from the Hoagland's solution. At 30 $\mathrm{d}$ after bloom, all the vines were destructively harvested. Each vine was divided into leaves, fruit clusters, new shoots, 2-yearold cane, shank, and roots. Average berry weight was determined from sampling 100 berries for each vine, and berry number per vine was calculated by dividing fruit yield with average berry weight. Total leaf area was measured with an LI-3000 leaf area meter (LI-COR, Lincoln, Nebr.). All the samples were dried in a forced air oven $\left(75^{\circ} \mathrm{C}\right.$ for $\left.4 \mathrm{~d}\right)$, weighed, and ground for total $\mathrm{N}$ and ${ }^{15} \mathrm{~N}$ analyses.
ANALYSIS OF NONSTRUCTURAL CARBOHYDRATES AND NITROGEN OF DORMANT VINES. Extraction and analysis of nonstructural carbohydrates of the composite samples were described previously (Xia and Cheng, 2004). Total nonstructural carbohydrates (TNC) were the sum of starch, sucrose, glucose, and fructose, which is also referred to as reserve carbohydrates throughout this paper.

Tissue $\mathrm{N}$ concentration was determined by combustion analysis using a $\mathrm{C} / \mathrm{N}$ analyzer (Carlo Erba NC2500, Carlo-Erba/Fisons Instruments, Valencia, Calif.). There are two types of $\mathrm{N}$ in a dormant vine: reserve $\mathrm{N}$ that can be remobilized to support new growth the following spring and structural $\mathrm{N}$ that can not. However, unlike the case of reserve carbohydrates, no chemical method had been developed to directly measure total reserve N. Therefore, total $\mathrm{N}$ was used to indicate reserve $\mathrm{N}$ status of a dormant vine in this paper, assuming reserve $\mathrm{N}$ was proportional to total $\mathrm{N}$.

${ }^{15}$ ANALYSIS AND CALCULATIONS. The isotopic ratios $\left({ }^{15} \mathrm{~N}:{ }^{14} \mathrm{~N}\right)$ of the samples harvested at the end of the regrowth period were measured at Isotope Services in Los Alamos, N.M. These ratios then were converted to atom $\%{ }^{15} \mathrm{~N}$ abundance using a natural abundance value of $0.3663 \%$ (Junk and Svec, 1958). The percentage of $\mathrm{N}$ derived from the labeled fertilizer (NDFF\%) was calculated as $\left(0.3663-\right.$ tissue atom $\left.\%{ }^{15} \mathrm{~N}\right) \times 100 \% /(0.3663$ - fertilizer atom $\%{ }^{15} \mathrm{~N}$ ). For vines that did not receive any $\mathrm{N}$ supply during the regrowth period, the amount of total $\mathrm{N}$ present in the new shoots, leaves, and fruit was considered as the amount of reserve $\mathrm{N}$ remobilized from the $\mathrm{N}$ storage pool to the new growth, by assuming that other sources provided negligible amount of $\mathrm{N}$ to vine growth. The total vine $\mathrm{N}$ accumulated from the previous year was the sum of $\mathrm{N}$ in the new growth (shoots, leaves, and fruit) and that in the 2-year-old cane, shank, and roots. For vines that received $10 \mathrm{~mm} \mathrm{~N}$ from the ${ }^{15} \mathrm{~N}$-depleted $\mathrm{NH}_{4} \mathrm{NO}_{3}$ during the regrowth period, the amount of reserve $\mathrm{N}$ remobilized for new shoots, leaves, and fruit was calculated as the difference between the total amount of $\mathrm{N}$ present in the new growth and that derived from the labeled fertilizer. Similarly, the total vine $\mathrm{N}$ accumulated from the previous year was obtained by totaling the amount of $\mathrm{N}$ that was not derived from the labeled fertilizer in the new growth (shoots, leaves, and fruit), 2-year-old cane, shank, and roots.

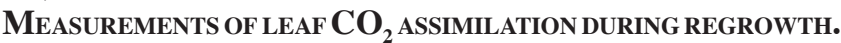
$\mathrm{CO}_{2}$ assimilation was monitored on selected leaves at 2 weeks before bloom, bloom, and 2 and 4 weeks after bloom during the regrowth period. Measurements were made under saturating light (photon flux density of 1400 to $1800 \mu \mathrm{mol} \cdot \mathrm{m}^{-2} \cdot \mathrm{s}^{-1}$ ), air temperature of 24 to $28{ }^{\circ} \mathrm{C}$ and ambient $\mathrm{CO}_{2}\left(360 \pm 5 \mu \mathrm{mol} \cdot \mathrm{mol}^{-1}\right)$ using a CIRAS-1 portable photosynthesis system (PP Systems, Herts, U.K.). The leaf on the opposite side of the second cluster was measured from 2 weeks before bloom to 2 weeks after bloom, whereas recent fully expanded leaves were used at 4 weeks after bloom.

STATISTICAL ANALYSIS. Data were analyzed by analysis of variance $($ ANOVA) for a $5(\mathrm{~N}$ fertigation $) \times 2($ foliar $\mathrm{N})$ or 5 $(\mathrm{N}$ fertigation $) \times 2$ (foliar urea) $\times 2$ (spring $\mathrm{N}$ supply) factorial experiment with a completely randomized design via SAS (SAS Institute, Cary, N.C.).

\section{Results}

TOTAL NITROGEN, TOTAL RESERVE CARBOHYDRATES, AND TOTAL CARBON IN RESERVE CARBOHYDRATES, PROTEINS, AND FREE AMINO ACIDS OF DORMANT VINES. On a whole-vine basis, total amount of $\mathrm{N}$ increased with increasing $\mathrm{N}$ supply from fertigation (Fig. 

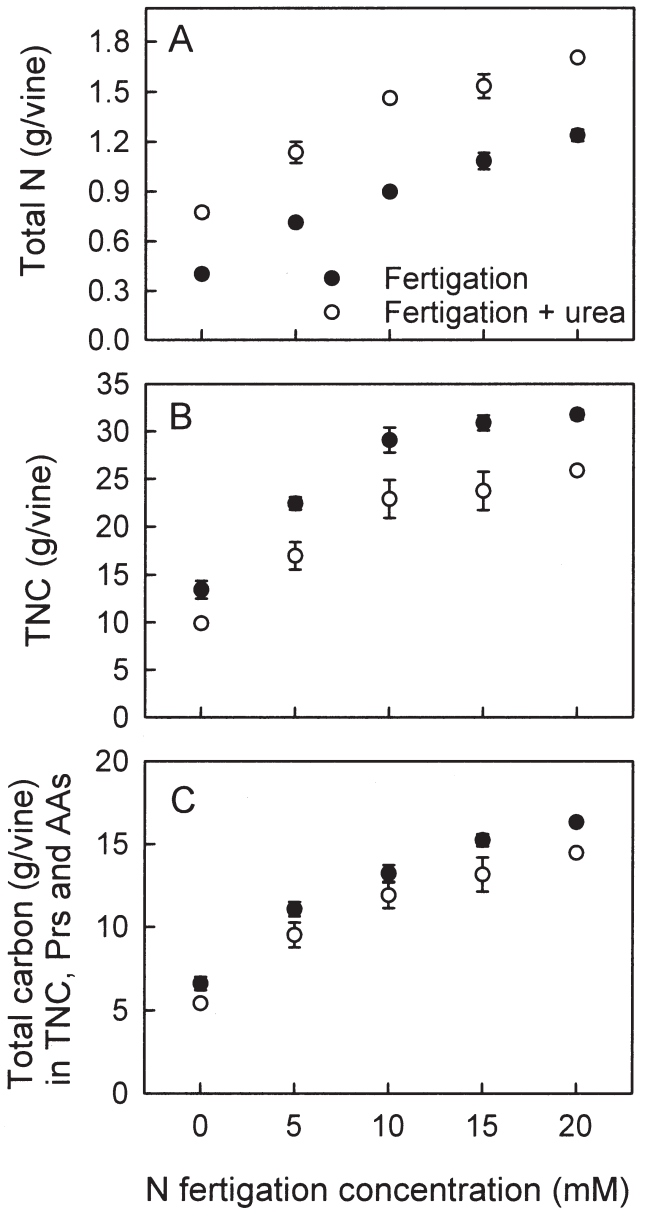

Fig. 1. Total N (A), total nonstructural carbohydrates (TNC) (B), and total carbon in TNC, proteins (Prs), and free amino acids (AAs) (C) of dormant 'Concord' grapevines in response to $\mathrm{N}$ fertigation during summer and foliar urea application in the fall. Vines were destructively sampled on 26 Mar. 2002 after pruning to 20 nodes per vine. Each point is a mean with standard error of four replicates. All three dependent variables were analyzed by analysis of variance for a 5 ( $\mathrm{N}$ fertigation $) \times 2$ (foliar urea) factorial experiment with a completely randomized design. In $(\mathbf{A})$ and $(\mathbf{B}), P$ values are $<0.0001$ for both $\mathrm{N}$ fertigation and foliar urea without significant interaction between the two. In (C), $P$ values are $<0.0001$ and 0.002 for $\mathrm{N}$ fertigation and foliar urea without significant interaction between the two.

1A). Total reserve carbohydrates increased with increasing $\mathrm{N}$ fertigation concentration from 0 to $10 \mathrm{~mm}$, then leveled off with further rises in $\mathrm{N}$ supply from fertigation (Fig. 1B). Total carbon in reserve carbohydrates, proteins, and free amino acids showed a curvilinear increase in response to $\mathrm{N}$ supply from fertigation (Fig. 1C). Foliar urea application in the fall increased total $\mathrm{N}$ but decreased total reserve carbohydrates and total carbon in reserve carbohydrates, proteins and free amino acids at each given $\mathrm{N}$ fertigation level.

VEGETATIVE GROWTH, FRUIT YIELD AND TOTAL VINE DRY WEIGHT. Vine vegetative growth and fruiting responded to previous-year $\mathrm{N}$ treatments and current-season $\mathrm{N}$ supply. When no $\mathrm{N}$ was provided during the regrowth period, vine total leaf area, fruit yield, and total dry weight increased with increasing $\mathrm{N}$ fertigation concentrations from the previous year (Fig. 2A-C). Vines sprayed with foliar urea the previous fall produced a larger total leaf area, a higher fruit yield, and a higher total dry weight at each given $\mathrm{N}$ fertigation level. This corresponded well with the total $\mathrm{N}$ in dormant vines (Fig. 1A). Providing vines with sufficient $\mathrm{N}$ during the regrowth period significantly increased total leaf area, fruit yield, and total dry weight across the previous $\mathrm{N}$ fertigation concentrations (Fig. 2D-F). Vines with a low $\mathrm{N}$ status responded more to current-season $\mathrm{N}$ supply than those with a high $\mathrm{N}$ status in terms of leaf area (Fig. 2D), but responded less in terms of yield (Fig. 2E). Nonetheless, vines sprayed with foliar urea the previous fall still had a larger total leaf area, a higher fruit yield, and a higher total dry weight than those that did not receive foliar urea applications at each given $\mathrm{N}$ fertigation concentration.

Both berry number and size were affected by vine reserve $\mathrm{N}$ status and current-season $\mathrm{N}$ supply. When no $\mathrm{N}$ was provided during the regrowth period, vines sprayed with foliar urea the previous fall had more berries per vine and larger berries than those that were not sprayed with foliar urea (Fig. 3A-B). Providing sufficient $\mathrm{N}$ in the current season significantly increased both berry number per vine and berry size (Fig. 3C-D). When grown under sufficient $\mathrm{N}$ supply, vines sprayed with foliar urea the previous fall still had a larger number of berries per vine, with berry size being the same, compared with vines that were not sprayed with foliar urea.

LEAF $\mathrm{CO}_{2}$ ASSIMILATION. Light-saturated $\mathrm{CO}_{2}$ assimilation, indicative of leaf function, responded to both vine reserve $\mathrm{N}$ status and current-season $\mathrm{N}$ supply. At 2 weeks before bloom, $\mathrm{CO}_{2}$ assimilation was higher in vines sprayed with foliar urea the previous fall than those not receiving foliar urea (Fig. 4 A, E). At bloom and 2 weeks after bloom, vines sprayed with foliar urea the previous fall still had higher $\mathrm{CO}_{2}$ assimilation than those not receiving foliar urea when no $\mathrm{N}$ was provided during regrowth (Fig. $4 \mathrm{~B}-\mathrm{C}$ ). Providing sufficient $\mathrm{N}$ in the current season increased $\mathrm{CO}_{2}$ assimilation of vines that did not receive foliar urea the previous fall to the same level of vines sprayed with foliar urea (Fig. 4F-G). At 4 weeks after bloom, all the vines had low $\mathrm{CO}_{2}$ assimilation regardless of foliar urea application the previous fall when no $\mathrm{N}$ was provided during the current season (Fig. 4D). Providing sufficient $\mathrm{N}$ in the current season increased $\mathrm{CO}_{2}$ assimilation of recent fully expanded leaves with vines that did not receive foliar urea having a slightly higher $\mathrm{CO}_{2}$ assimilation than those sprayed with foliar urea the previous fall (Fig. 4H).

REMOBILIZATION OF RESERVE N FOR NEW GROWTH. When no N was provided during regrowth, approximately $40 \%$ of the total vine $\mathrm{N}$ was remobilized to support the growth of new shoots, leaves, and fruit clusters for vines that did not receive foliar urea the previous fall (Fig. 5A). Foliar urea application the previous fall increased the remobilization rate to about $50 \%$ across the $\mathrm{N}$ fertigation concentrations. Providing sufficient $\mathrm{N}$ in the current season did not significantly affect remobilization of reserve $\mathrm{N}$ (Fig. 5B).

Contribution of Reserve $\mathbf{N}$ and Current $\mathbf{N}$ UPTAKe. The contribution of reserve $\mathrm{N}$ to shoot and leaf growth increased as $\mathrm{N}$ supply from previous $\mathrm{N}$ fertigation increased (Fig. 6A). Foliar urea application the previous fall increased this percentage of contribution at each given $\mathrm{N}$ fertigation level. The contribution of reserve $\mathrm{N}$ to fruit showed a similar trend as that to shoots and leaves, but the actual percentage was much lower than in shoots and leaves at the same N status (Fig. 6B).

The total uptake of $\mathrm{N}$ during the current season was not affected by $\mathrm{N}$ fertigation or foliar urea application the previous year (Fig. 7A). The relative contribution of current $\mathrm{N}$ uptake to total vine $\mathrm{N}$ decreased with increasing $\mathrm{N}$ supply from fertigation 


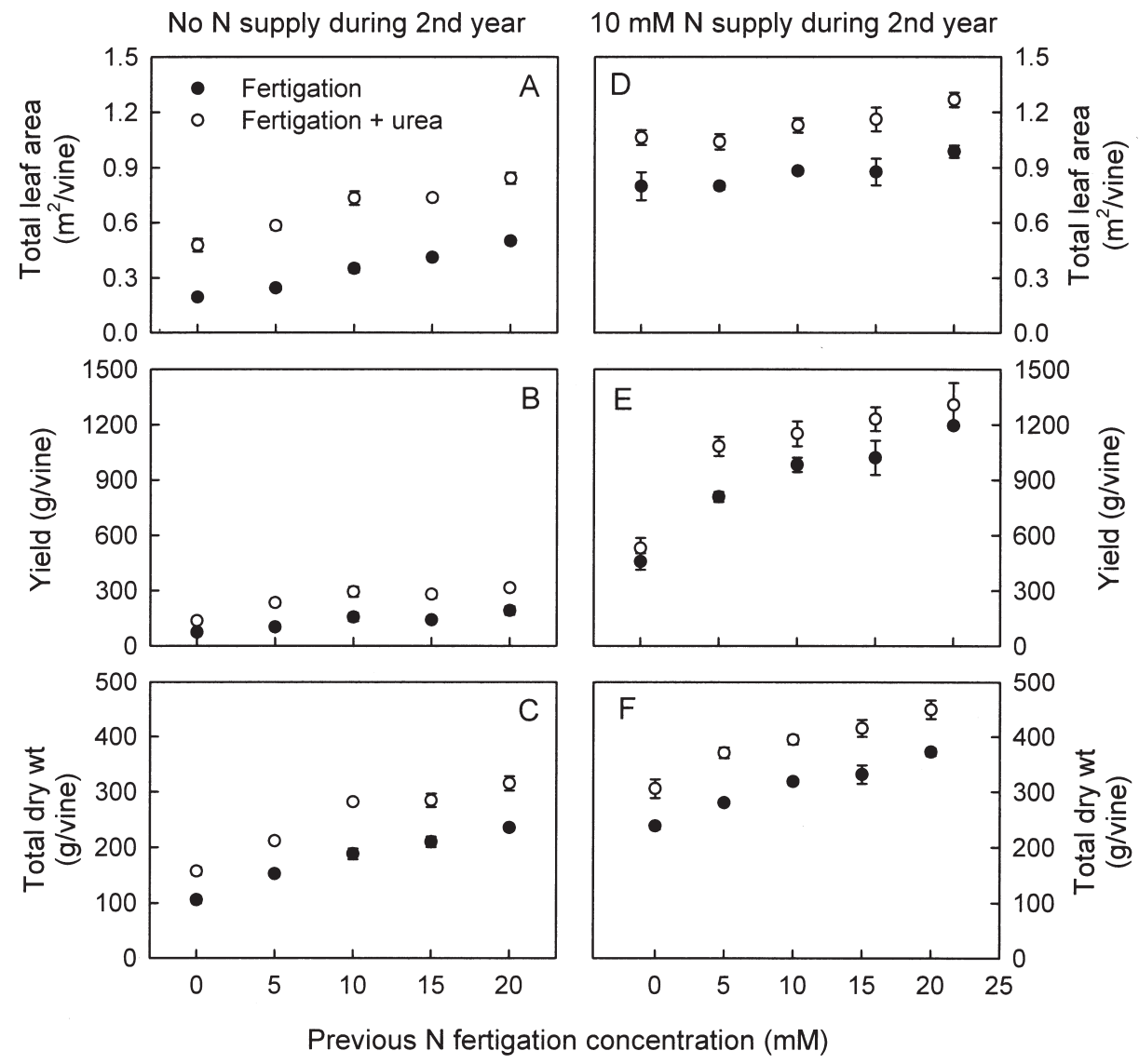

Fig. 2. Total leaf area, fruit yield, and total dry weight of 'Concord' grapevines at the end of the regrowth period in relation to previous $\mathrm{N}$ fertigation and foliar urea application when grown under no $\mathrm{N}(\mathbf{A}, \mathbf{B}, \mathbf{C})$ or $10 \mathrm{~mm} \mathrm{~N}(\mathbf{D}$, E, F) supply from 2 weeks before bloom to 1 month after bloom. Each point is a mean with standard error of four replicates. All three dependent variables were analyzed by analysis of variance for a 5 ( $\mathrm{N}$ fertigation) $\times 2$ (foliar urea) $\times 2$ (spring $\mathrm{N}$ ) factorial experiment with a completely randomized design. For total leaf area, $P$ values are all $<0.0001$ for $\mathrm{N}$ fertigation, foliar urea, and spring $\mathrm{N}$ supply, 0.037 and 0.034 for the interaction between $\mathrm{N}$ fertigation and spring $\mathrm{N}$ supply and between foliar $\mathrm{N}$ and spring $\mathrm{N}$ supply. For yield, $P$ values are all $<0.0001$ for $\mathrm{N}$ fertigation, foliar urea, spring $\mathrm{N}$ supply, and the interaction between $\mathrm{N}$ fertigation and spring $\mathrm{N}$ supply. For total dry weight, $P$ values are all $<0.0001$ for $\mathrm{N}$ fertigation, foliar urea, and spring $\mathrm{N}$ supply with no significant interaction.

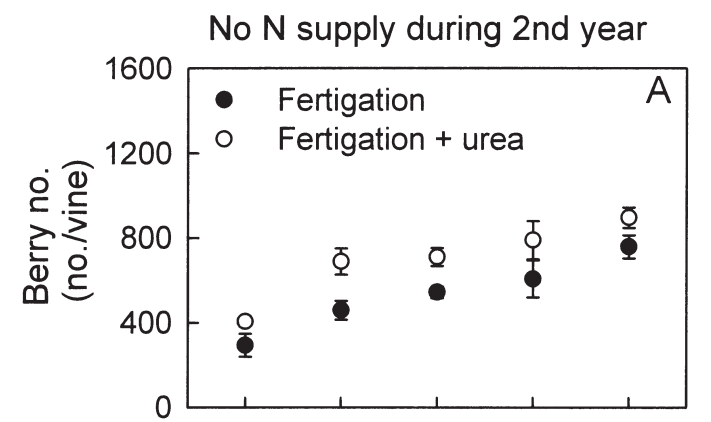

$10 \mathrm{mM} \mathrm{N}$ supply during $2 \mathrm{nd}$ year
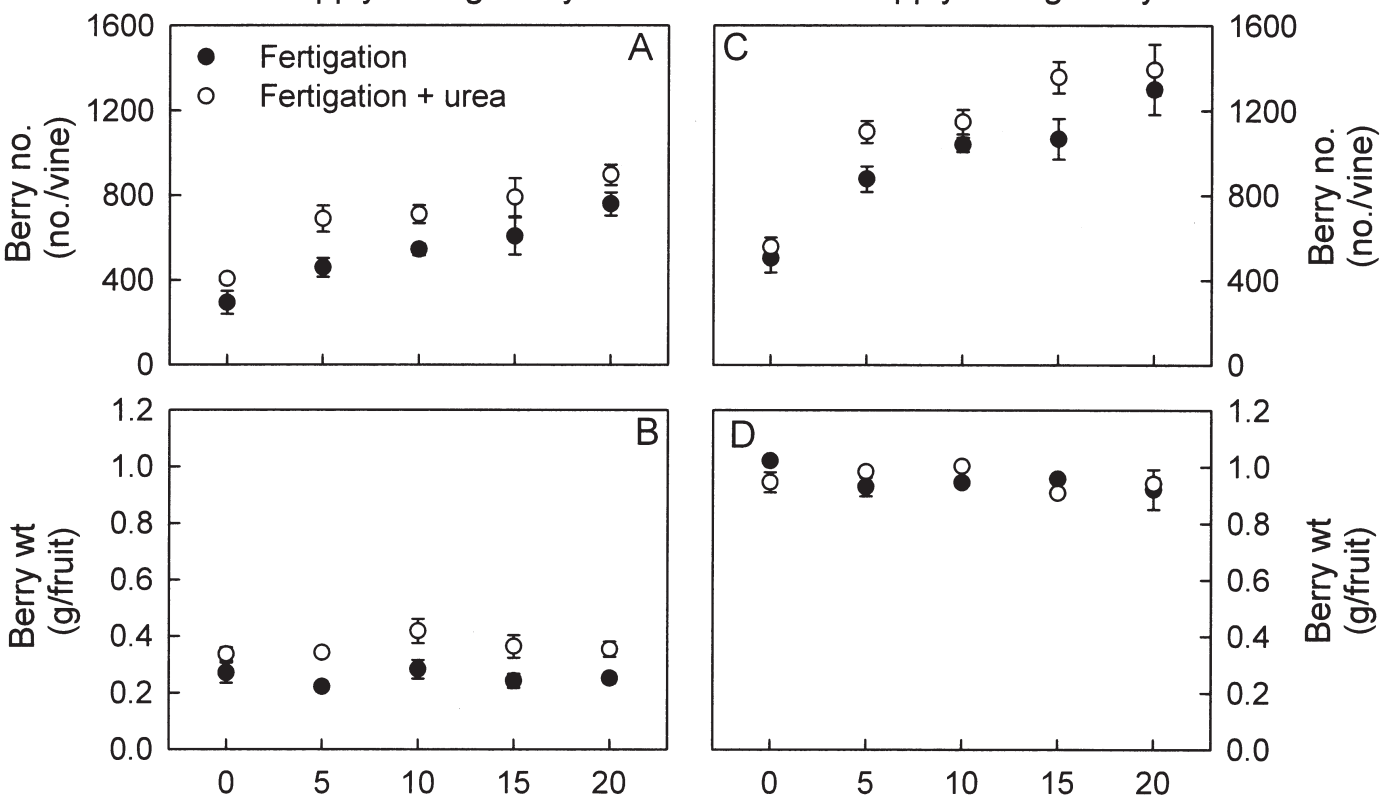

Previous $\mathrm{N}$ fertigation concentration (mM)

Fig. 3. Berry number and berry size of 'Concord' grapevines at the end of the regrowth period in relation to previous $\mathrm{N}$ fertigation and foliar urea application when grown under no $\mathrm{N}(\mathbf{A}, \mathbf{B})$ or $10 \mathrm{~mm} \mathrm{~N}(\mathbf{C}, \mathbf{D})$ supply from 2 weeks before bloom to 1 month after bloom. Each point is a mean with standard error of four replicates. Data were analyzed by analysis of variance for a 5 ( $\mathrm{N}$ fertigation) $\times 2$ (foliar urea) $\times 2$ (spring $\mathrm{N}$ ) factorial experiment with a completely randomized design. For berry number, $P$ values are all $<0.0001$ for $\mathrm{N}$ fertigation, foliar urea, and spring $\mathrm{N}$ supply, and 0.001 for the interaction between $\mathrm{N}$ fertigation and spring N. For berry size, $P$ values are $0.0003,<0.0001$, and $<0.0001$ for foliar $\mathrm{N}$, spring $\mathrm{N}$, and the interaction between the two with no significant effect of $\mathrm{N}$ fertigation $(P>0.05)$. 

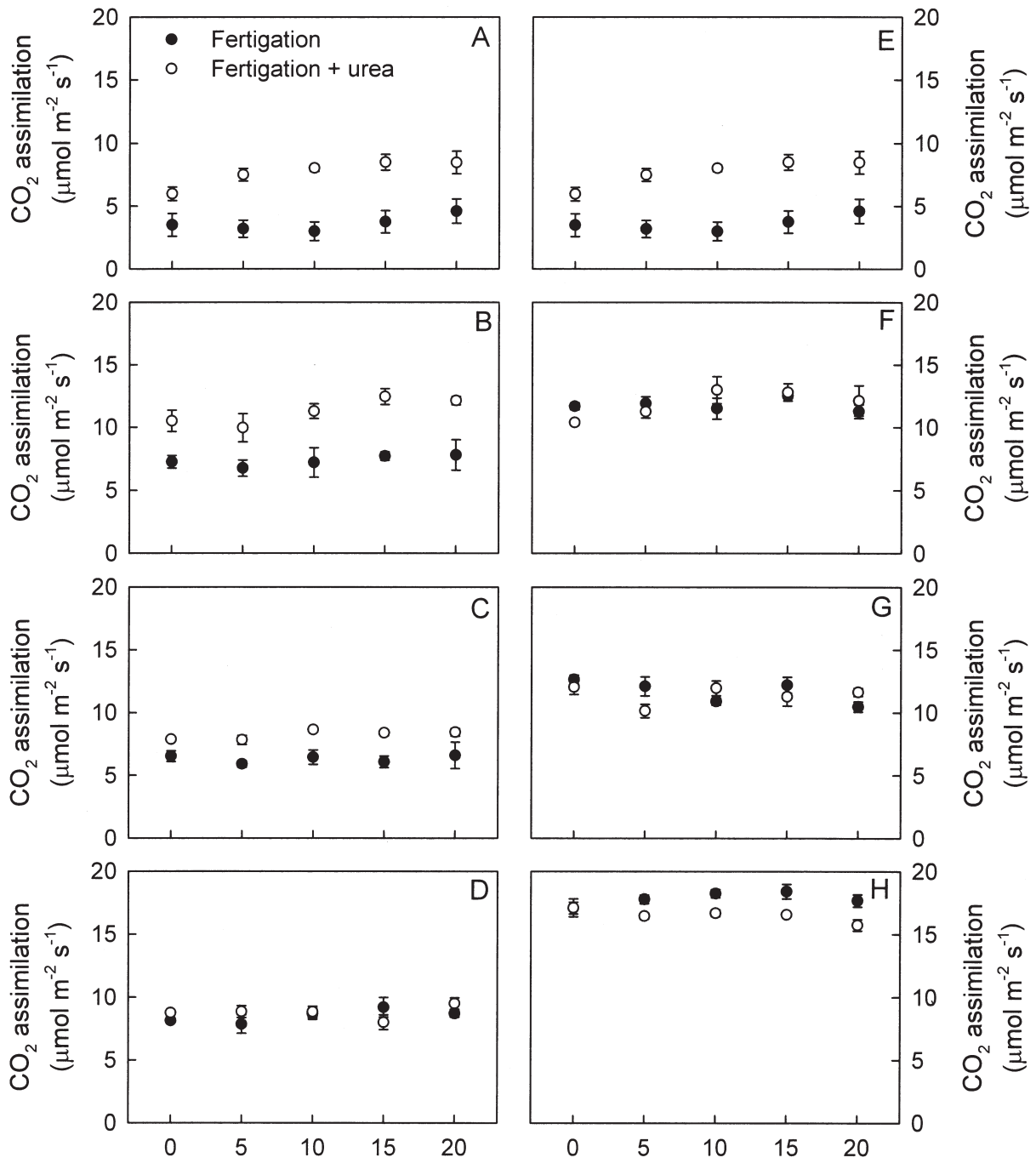

Previous $\mathrm{N}$ fertigation concentration (mM)
Fig. 4. Leaf $\mathrm{CO}_{2}$ assimilation of 'Concord' grapevines at 2 weeks before bloom (A, E), bloom (B, F), 2 weeks after bloom $(\mathbf{C}, \mathbf{G})$ and 4 weeks after bloom $(\mathbf{D}, \mathbf{H})$ in relation to previous $\mathrm{N}$ fertigation and foliar urea application when grown under no $\mathrm{N}(\mathbf{A}, \mathbf{B}, \mathbf{C}, \mathbf{D})$ or $10 \mathrm{~mm} \mathrm{~N}(\mathbf{E}, \mathbf{F}, \mathbf{G}$, H) supply from 2 weeks before bloom to 1 month after bloom. Each point is a mean with standard error of four replicates. $\mathrm{CO}_{2}$ assimilation was analyzed by analysis of variance (ANOVA) for a 5 ( $\mathrm{N}$ fertigation) $\times 2$ (foliar urea) $\times 2$ (spring $\mathrm{N}$ ) factorial experiment for each measuring date except that data at 2 weeks before bloom were analyzed by ANOVA for a 5 (N fertigation) $\times 2$ (foliar urea) factorial design. Two weeks before bloom: $P$ value is $<0.0001$ for foliar urea with no significant effect of $\mathrm{N}$ fertigation $(P>0.05)$. Atbloom: $P$ values are all $<0.0001$ for foliar urea, spring $\mathrm{N}$, and the interaction between the two with no significant effect of $\mathrm{N}$ fertigation $(P>$ $0.05)$. Two weeks after bloom: $P$ values are $0.005,<0.0001,<0.001$ for foliar urea, spring $\mathrm{N}$, and the interaction between the two with no significant effect of $\mathrm{N}$ fertigation $(P>0.05)$. Four weeks after bloom: $P$ values are $0.02,<0.0001,0.0004$ for foliar urea, spring $\mathrm{N}$, and the interaction between the two with no significant effect of $\mathrm{N}$ fertigation $(P>0.05)$.

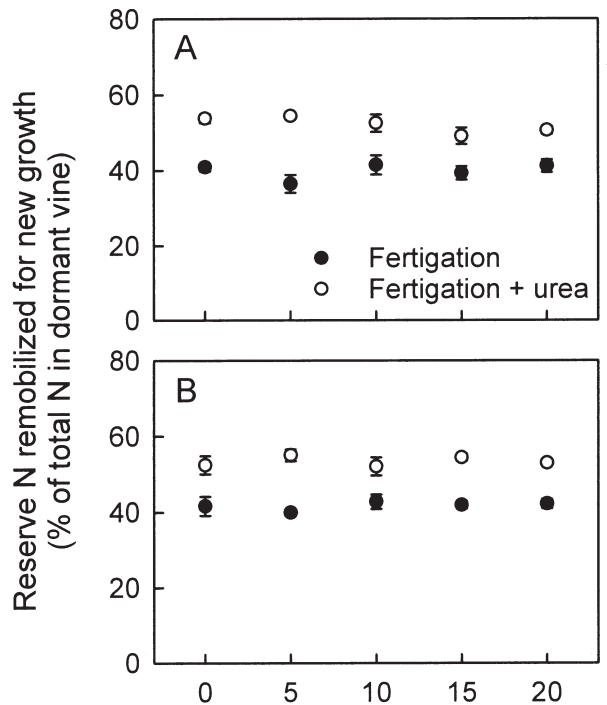

Previous $\mathrm{N}$ fertigation concentration ( $\mathrm{mM}$ ) during the previous year (Fig. 7B). Foliar urea application the previous fall decreased the relative contribution of current $\mathrm{N}$ uptake to total vine $\mathrm{N}$ across the previous $\mathrm{N}$ supply from fertigation.

\section{Discussion}

Foliar urea application in the fall significantly increased total N, whereas it decreased reserve carbohydrates and total carbon in reserve carbohydrates, proteins, and free amino acids (Fig. 1) without affecting vine size (Xia and Cheng, 2004). This made it possible to determine vine vegetative growth and fruiting in relation to reserve $\mathrm{N}$ and carbohydrates. Regardless of current-season $\mathrm{N}$ supply, vines with higher $\mathrm{N}$ reserves but lower carbohydrate reserves produced a larger total leaf area, higher fruit yield, and higher total dry weight than those with lower $\mathrm{N}$ reserves but higher carbohydrate reserves

Fig. 5. Reserve N remobilized for new growth (shoots, leaves, and fruit) of 'Concord' grapevines at the end of the regrowth period in relation to previous $\mathrm{N}$ fertigation and foliar urea application when grown under no $\mathrm{N}(\mathbf{A})$ or $10 \mathrm{~mm} \mathrm{~N}$ (B) supply from 2 weeks before bloom to 1 month after bloom. Each point is a mean with standard error of four replicates. $\mathrm{N}$ remobilization (\%) was analyzed by analysis of variance for a $5(\mathrm{~N}$ fertigation $) \times 2$ (foliar urea) $\times 2($ spring $\mathrm{N})$ factorial experiment with a completely randomized design. $P$ value is $<0.0001$ for foliar urea with no significant effect of $\mathrm{N}$ fertigation or spring $\mathrm{N}$ supply $(P>0.05)$. 


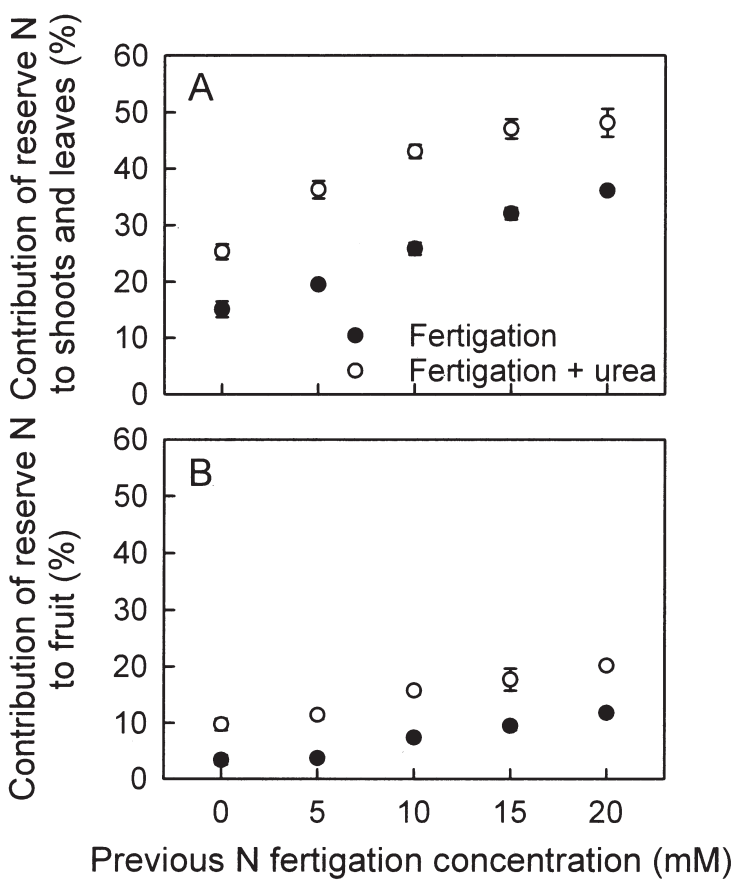

Fig. 6. Contribution of reserve $\mathrm{N}$ to new shoots and leaves (A) and to fruit (B) of 'Concord' grapevines at the end of the regrowth period in relation to previous $\mathrm{N}$ fertigation and foliar urea application for the vines grown under $10 \mathrm{~mm} \mathrm{~N}$ supply from 2 weeks before bloom to 1 month after bloom. Each point is a mean with standard error of four replicates. Both dependent variables were analyzed by analysis of variance for a 5 ( $\mathrm{N}$ fertigation) $\times 2$ (foliar urea) factorial experiment with a completely randomized design. In both (A) and (B), $P$ values are all $<0.0001$ for $\mathrm{N}$ fertigation and foliar urea with no significant interaction between the two.

at any given vine size (Fig. 2). This holds true even when the total carbon in reserve carbohydrates, proteins, and free amino acids was compared between vines with or without the foliar urea treatment (Fig. 1C). These data clearly indicate that both vegetative growth and fruiting of young grapevines in the spring are determined by reserve $\mathrm{N}$, not by reserve carbohydrates. This is in agreement with the finding in young apple trees (Cheng and Fuchigami, 2002), but contrasts with the conventional view that vine growth in the spring is largely determined by reserve carbohydrates. Although reserve carbohydrate concentrations in storage tissues decreased as growth resumed in the spring (Bates et al., 2002) and early defoliation in the fall led to reductions in vine growth the following season (Goffinet, 2001; Howell et al., 1978; Scholefield et al., 1978), a causal relationship between reserve carbohydrate level and growth cannot be established because vine $\mathrm{N}$ concentrations changed in the same direction as reserve carbohydrates in both cases.

Our finding that growth and fruiting of young grapevines in the spring are not determined by reserve carbohydrates does not have any conflict with the fact that carbohydrates are essential for the initial growth and development of grapevines in the spring. In 'Delaware' grapevines, about $11 \%$ to $15 \%$ of the ${ }^{14} \mathrm{C}$ assimilated in the fall that was retained in the vine after pruning was re-translocated by the time of bloom to support vine growth and development (Yang and Hori, 1979; Yang et al., 1980), and up to the five-leaf stage, the carbon supply for shoot growth was almost exclusively provided by reserves (Yang and Hori, 1980). However, it appears that reserve carbohydrates were not limiting for the initial growth and development of the vines that

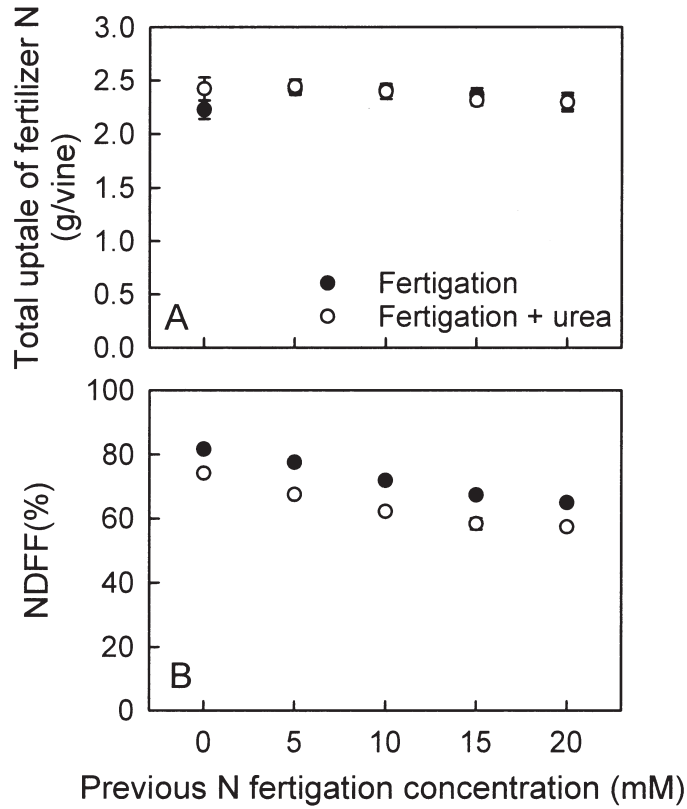

Fig. 7. Total N uptake of 'Concord' grapevines from the current season (A) and its contribution to the total vine $\mathrm{N}$ economy $(\mathbf{B})$ at the end of the regrowth period in relation to previous $\mathrm{N}$ fertigation and foliar urea application for the vines grown under $10 \mathrm{~mm} \mathrm{~N}$ from 2 weeks before bloom to 1 month after bloom. NDFF: nitrogen derived from fertilizer. Each point is a mean with standard error of four replicates. Both dependent variables were analyzed by analysis of variance for a 5 ( $\mathrm{N}$ fertigation) $\times 2$ (foliar urea) factorial experiment with a completely randomized design. In (A), there is no significant effect of $\mathrm{N}$ fertigation or foliar urea $(P>0.05)$. In $(\mathbf{B}), P$ values are $<0.0001$ for $\mathrm{N}$ fertigation and foliar urea with no significant interaction between the two.

did not receive foliar urea application in our experiment. When extra $\mathrm{N}$ (foliar urea) was provided the previous fall to convert some of the carbohydrates to proteins and amino acids in these vines (Xia and Cheng, 2004), the reserve carbohydrates were better used for growth and development the following spring. Therefore, reserve $\mathrm{N}$ plays a critical role in the utilization of reserve carbohydrates for the initial growth and development of grapevines in the spring.

The elevated reserve $\mathrm{N}$ level in the vines sprayed with foliar urea not only stimulated shoot growth and leaf area development, but also enhanced leaf $\mathrm{CO}_{2}$ assimilation early in the season (Fig. 4) because there was a close relationship between leaf $\mathrm{N}$ content and $\mathrm{CO}_{2}$ assimilation capacity in 'Concord' grapevines (Chen and Cheng, 2003). This is expected to improve carbon supply for vine growth and development prior to bloom, although the whole-plant net $\mathrm{CO}_{2}$ assimilation was not measured in this study. Our $\mathrm{CO}_{2}$ assimilation data (Fig. 4) also clearly showed that reserve $\mathrm{N}$ alone cannot sustain leaf function and that current-season $\mathrm{N}$ supply is important for improving vine growth and leaf function from bloom on.

Under adequate $\mathrm{N}$ supply during regrowth, the percent contribution of reserve $\mathrm{N}$ to the new growth depends on vine $\mathrm{N}$ status. Reserve $\mathrm{N}$ contributed a higher percentage to shoots and leaves and to fruit in vines sprayed with foliar urea than in those not receiving foliar urea (Fig. 6). The percent contribution of reserve $\mathrm{N}$ to shoots and leaves ranged from $15 \%$ in vines with the lowest $\mathrm{N}$ content to $48 \%$ in the vines with the highest $\mathrm{N}$ content (Fig. $6 \mathrm{~A}$ ), which was much lower than the corresponding values ( $43 \%$ 
to $90 \%$ ) found in young apple trees in a comparable study (Cheng and Fuchigami, 2002). This indicates that grapevines with vigorous vegetative growth depend less on reserve $\mathrm{N}$ and more on current $\mathrm{N}$ supply. At the same vine $\mathrm{N}$ status, fruit received much less contribution from reserve $\mathrm{N}$ compared with shoots and leaves (Fig. 6B). This is because berry development starts much later than shoot growth. The higher dependence of fruit growth on current $\mathrm{N}$ supply explains why providing sufficient $\mathrm{N}$ during the current season had such a large effect on fruit yield (Fig. 2E).

The finding that fall foliar urea application increased the proportion of vine $\mathrm{N}$ content remobilized for the growth of new shoots, leaves, and fruit (Fig. 5) is similar to that observed in young almond [Prunus dulcis (Mill) D.A. Webb] trees (Bi et al., 2003) and poplar (Populus spp.) cuttings (Dong et al., 2004). This is also consistent with the result obtained on nectarine [Prunus persica (L.) Batsch var. nectarina] trees, where soil $\mathrm{N}$ application late in the season after cessation of shoot growth contributed more to $\mathrm{N}$ storage than early application during active shoot growth (Tagliavini, et al., 1999). In young apple trees, however, the remobilization rate was not significantly affected by foliar urea application in the fall (Cheng and Fuchigami, 2002). This difference may be related to the fact that grapevines have more vigorous vegetative growth than apple trees. As a result, a larger proportion of the $\mathrm{N}$ taken up during active vine growth is used for structural growth and less is available for storage. Only when vegetative growth slows down or stops will the $\mathrm{N}$ taken up be primarily used for storage. For potted 'Chenin blanc' grapevines grown in a warm climate with a long postharvest period, $\mathrm{N}$ uptake during the postharvest period comprised $27 \%$ to $34 \%$ of the total annual $\mathrm{N}$ uptake (Conradie, 1980, 1986) and provided $60 \%$ of the stored $\mathrm{N}$ for the next season (Conradie, 1992). Our finding that current-season $\mathrm{N}$ supply did not affect remobilization of reserve $\mathrm{N}$ for new growth is similar to that reported for apple (Cheng and Fuchigami, 2002; Millard and Neilsen, 1989) and many other woody plants (Millard, 1996).

In conclusion, both vegetative growth and fruiting of young grapevines in the spring are largely determined by reserve $\mathrm{N}$, not by reserve carbohydrates. Current-season $\mathrm{N}$ supply plays an important role in sustaining vine growth and development, especially fruit growth.

\section{Literature Cited}

Bates, T., R. Dunst, and P. Joy. 2002. Seasonal dry matter, starch, and nutrient distribution in 'Concord' grapevine roots. HortScience 37:313-316.

Bi, G., C.F. Scagel, L. Cheng, S. Dong, and L.H. Fuchigami. 2003. Spring growth of almond nursery trees depends upon nitrogen from both plant reserves and spring fertilizer application. J. Hort. Sci. Biotech. 78:853-858.

Chen, L.S. and L. Cheng. 2003. Carbon assimilation and carbohydrate metabolism of 'Concord' grape (Vitis labrusca L.) leaves in response to nitrogen supply. J. Amer. Soc. Hort. Sci. 128:754-760.

Cheng, L. and L.H. Fuchigami. 2000. Rubisco activation state decreases with increasing nitrogen content in apple leaves. J. Expt. Bot. 51:1687-1694.

Cheng, L. and L.H. Fuchigami. 2002. Growth of young apple trees in relation to reserve nitrogen and carbohydrates. Tree Physiol. 22:1297-1303.

Conradie, W.J. 1980. Seasonal uptake of nutrients by Chenin blanc in sand culture: I. Nitrogen. South Afr. J. Enol. Viticult. 1:59-65.

Conradie, W.J. 1986. Utilization of nitrogen by the grapevine as affected by time of application and soil type. South Afr. J. Enol. Viticult. 7:76-83.

Conradie, W.J. 1992. Partitioning of nitrogen in grapevines during autumn and the utilization of nitrogen reserves during the following growing season. South Afr. J. Enol. Viticult. 13:45-51.

Dong, S., L. Cheng, C.F. Scagel, and L.H. Fuchigami. 2004. Nitrogen mobilization, nitrogen uptake and growth of cuttings obtained from poplar stock plants grown in different $\mathrm{N}$ regimes and sprayed with urea in autumn. Tree Physiol. 24:355-359.

Faby, R. and W.D. Naumann. 1986. Effects of defoliation of apple trees after harvest. II. Mineral and carbohydrate contents in shoots, crop yield. Gartenbauwissenschaft 51:136-142.

Goffinet, M.C. 2001. Flower "Malady" and poor fruit set of grapevines with respect to training system, cropload, shoot growth, and cane carbohydrate reserves, p. 81-87. In: Viticult. Consortium-East Program Final Rpts. for 2000. New York State Agr. Expt. Sta., Geneva.

Guak, S., L. Cheng, and L.H. Fuchigami. 2001. Foliar urea pretreatment tempers inefficient $\mathrm{N}$ recovery resulting from copper chelate defoliation of apple nursery plants. J. Hort. Sci. Biotechn. 76:35-39.

Howell, G.S. 2001. Sustainable grape productivity and the growth-yield relationship: A review. Amer. J. Enol. Viticult. 52:165-174.

Howell, G.S. B.G. Stergios, and S.S. Stackhouse. 1978. Interrelation of productivity and cold hardiness of Concord grapevines. Amer. J. Enol. Viticult. 29:187-191.

Junk, G. and H.J. Svec. 1958. The absolute abundance of the nitrogen isotopes in the atmosphere and compressed gas from various sources. Geochimica et Cosmochimica Acta 14:234-243.

Millard, P. and G.H. Neilsen. 1989. The influence of nitrogen and supply on the uptake and remobilization of stored $\mathrm{N}$ for the seasonal growth of apple trees. Ann. Bot. 63:301-309.

Millard, P. 1996 Ecophysiology of internal cycling of nitrogen for tree growth. J. Plant Nutr. Soil Sci. 159:1-10.

Scholefield, P.B., T.F. Neales, and P. May. 1978. Carbon balance of the Sultana vines (Vitis vinifera $\mathrm{L}$.) and the effects of autumn defoliation by harvest-pruning. Austral. J. Plant Physiol. 5:561-570.

Tagliavini, M., P. Millard, M. Quartieri, and B. Marangoni. 1999. Timing of nitrogen uptake affects winter storage and spring remobilization of nitrogen in nectarine (Prunus persica var. nectarina) trees. Plant Soil 211:149-153.

Wermelinger, B. 1991. Nitrogen dynamics in grapevine: physiology and modeling, p. 23-31. In: J.M. Rantz (ed.). Proc. Intl. Symp. Nitrogen in Grapes and Wine. Amer. Soc. Enol. Viticult., Davis, Calif.

Williams, L.E. 1991. Vine nitrogen requirements-Utilization of $\mathrm{N}$ sources from soils, fertilizers, and reserves, p. 62-66. In: J.M. Rantz (ed.). Proc. Intl. Symp. Nitrogen in Grapes and Wine. Amer. Soc. Enol. Viticult, Davis, Calif.

Xia, G. and L. Cheng. 2004. Foliar urea application in the fall affects both nitrogen and carbon storage in young 'Concord' grapevines grown under a wide range of nitrogen supply. J. Amer. Soc. Hort. Sci. 129:653-659.

Yang, Y.S. and Y. Hori. 1979. Studies on retranslocation of accumulated assimilates in 'Delaware' grapevines. I. Retranslocation of ${ }^{14} \mathrm{C}$-assimilates in the following spring after ${ }^{14} \mathrm{C}$ feeding in summer and autumn. Tohoku J. Agr. Res. 30:43-56.

Yang, Y.S. and Y. Hori. 1980. Studies on retranslocation of accumulated assimilates in 'Delaware' grapevines. III. Early growth of new shoots as dependent on accumulated and current year assimilates. Tohoku J. Agr. Res. 31:120-129.

Yang, Y.S., Y. Hori, and R. Ogata. 1980. Studies on retranslocation of accumulated assimilates in 'Delaware' grapevines. II. Retranslocation of assimilates accumulated during the previous growing season. Tohoku J. Agr. Res. 31:109-119. 